\title{
Rainforest to Reef: A Landscape-scale Approach to Coastal Ecotourism in Malaysia
}

\author{
Lincoln Garland ${ }^{1}$, Mike Wells ${ }^{1}$, Keith French ${ }^{2}$ \& John Dawkins ${ }^{2}$ \\ ${ }^{1}$ Biodiversity by Design Ltd, Monkton Combe, Bath, United Kingdom \\ ${ }^{2}$ Grant Associates, Bath, United Kingdom \\ Corresponding Author: Lincoln Garland; E: lincoln.garland@biodiversitybydesign.co.uk
}

\begin{abstract}
In 1990 the Malaysian Government launched Vision 2020 with the goal of Malaysia becoming a 'fully developed country' by the year 2020. In this drive for development the country has been examining many of its key natural assets, exploring how to both preserve them whilst ensuring that they make the maximum possible contribution to national development goals. Endau Rompin is one of these assets, being the second largest National Park in Peninsula Malaysia. The rich tropical rainforest flora and fauna of the Park and its hinterland, however, are threatened by various anthropogenic forces, most notably deforestation and poaching; both of which have taken the Park's flagship species - the Tiger Panthera tigris jacksoni - towards the brink of local extinction. Malaysia's statutory East Coast Economic Region Development Council commissioned a study to consider ways of increasing tourism revenues from the Park while at the same time reversing these threats. The key conclusion drawn is that a more holistic, landscape-scale approach should be adopted, with Endau Rompin forming part of a wider strategic economic zone based around sustainable tourism and land management. The proposed expanded zone extends eastwards beyond the confines of the Park, across the coastal plain to the South China Sea, and onwards to the neighbouring Mersing Islands. This expanded zone is referred to as Malaysia's new 'Rainforest to Reef Region'.
\end{abstract}

Keywords: Malaysia; Endau Rompin; landscape-scale management; ecotourism; rainforest to reef; Tiger 


\section{Introduction}

According to the Commission on Growth \& Development (2008) Malaysia is one of the world's '13 Success Stories', being one of only thirteen developing nations to have achieved sustained and substantial economic growth since 1945. This rapid progress gave the nation confidence in 1990 to launch its ambitious 'Vision 2020' programme, with the goal of Malaysia becoming a 'fully developed country' by the year 2020. Malaysia is also ranked, by certain measures at least, among the world's top ten tourist destinations, benefitting from its tropical climate, beaches, islands, cultural diversity, and natural environment (Mosbah \& Khuja, 2014; Maps of the World, 2016). Given these attributes the Government has positioned tourism at the economic forefront of Vision 2020 and in particular believes that ecotourism has 'tremendous potential' for expansion.

In support of its ecotourism goal the Malaysian Government has been examining many of its key natural assets, exploring how to both preserve them whilst ensuring that they make the maximum possible contribution to national development objectives. Endau Rompin National Park (hereafter also referred to as 'the Park') is one of these assets, being the second largest National Park in Peninsula Malaysia. The Park, which spans the state border between Johor and Pahang, is c. $175 \mathrm{~km}$ south-east of Kuala Lumpur and c. 125km north of Singapore (Figure 1). Endau Rompin has numerous natural assets, including virgin tropical rainforest, spectacular landforms, and variety of rare and in many cases 'charismatic' fauna, principal amongst which is the Malaysian Tiger Panthera tigris jacksoni (Figure 2). The Government's East Coast Economic Region Development Council (ECERDC) commissioned a Strategic Implementation Plan (SIP) for the Park to determine how it might become an internationally recognised ecotourism destination, thereby accelerating the economic growth of the East Coast Economic Region in a 'viable, equitable and sustainable manner'.

The Malaysian Government has recognised that many of the nation's naturebased resources are not reaching their full tourism potential due to negative international perceptions related to deforestation, the growth of oil palm plantations, and often significant limitations of infrastructure (PEMANDU, 2010). Endau Rompin National Park is no exception in this regard, with a record of low visitor numbers and some concerns about visitor satisfaction. For example, in spite of Endau Rompin's 


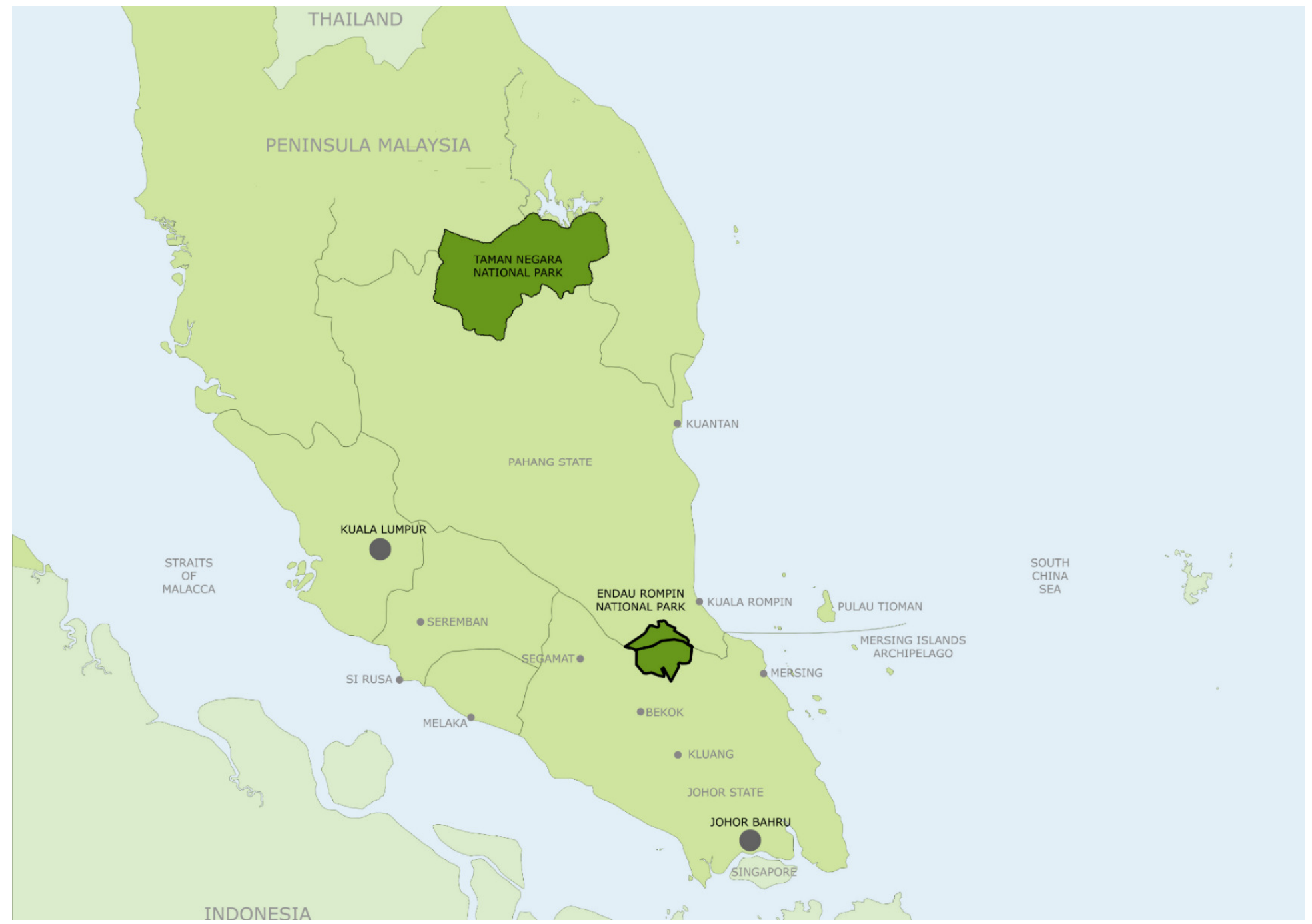

Figure 1. Endau Rompin National Park context, Peninsula Malaysia's second largest national park; the largest National Park - Taman Negara - is also shown 


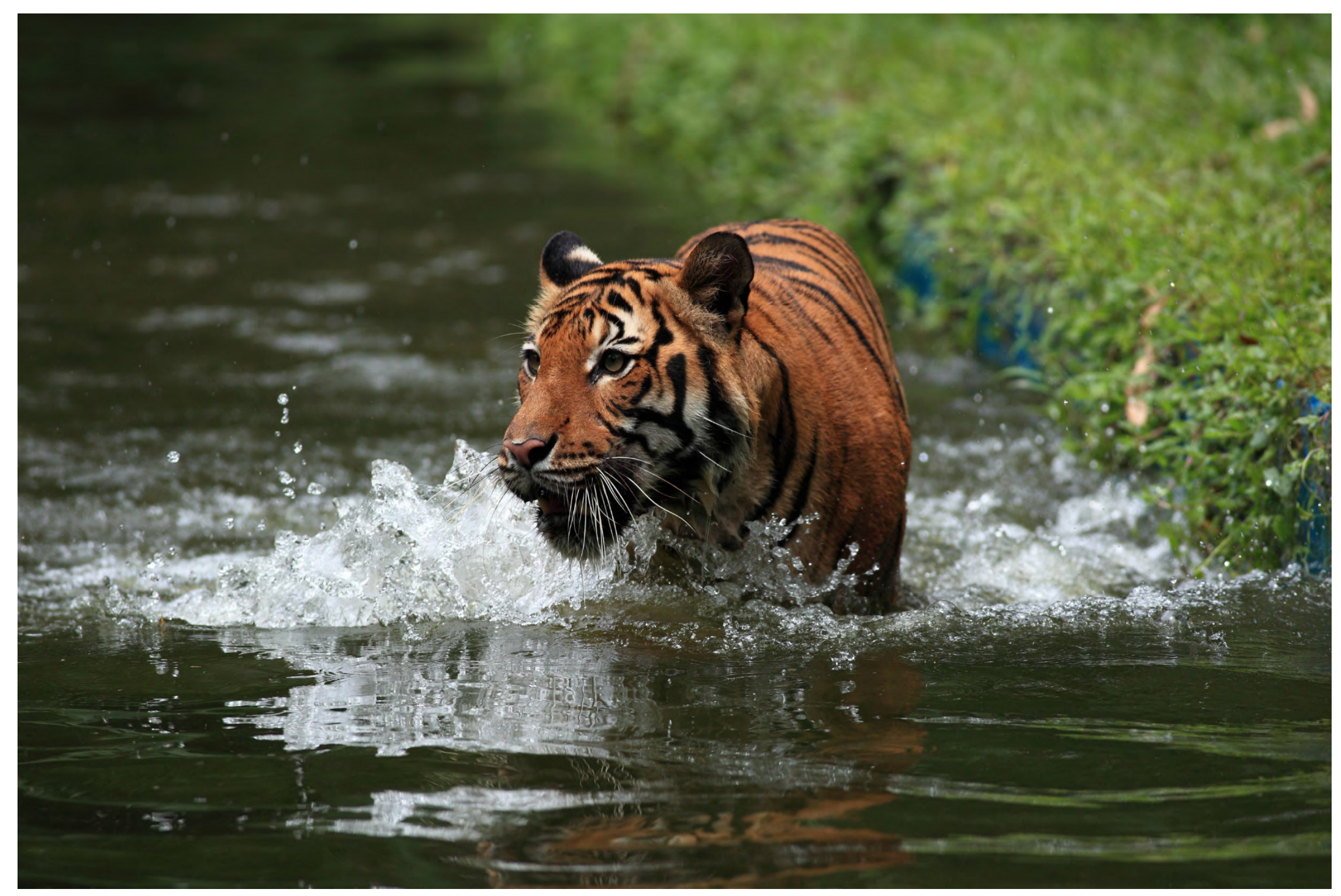

Figure 2. Malaysian Tiger; Endau Rompin's flagship species and Malaysia's national emblem 
impressive natural qualities the Park has only been attracting c. 10,000 visitors per annum which generates negligible revenue. By comparison similar-sized Daintree National Park in Australia attracts approximately 400,000 visitors per annum and makes a significant contribution to the Queensland economy (Daintree Discovery Centre, 2015; Queensland Parks \& Wildlife Service, 2016).

Previous approaches to improving the Park's ecotourism offer have focussed on new or improved tourist facilities such as eco-lodges, visitor centres, hiking trails and roads. In the course of the SIP study, however, it became apparent that such a narrow focus would fail to protect the key biodiversity of the park, and equally fail to deliver significant socio-economic gains locally and at a wider scale. Without adopting a truly sustainable and holistic approach to tourism and development, the integrity of the Park's ecosystems is likely to become progressively impoverished in the face of various anthropogenic pressures, key amongst which are deforestation and poaching; pressures that have, inter alia, taken the Park's flagship species and national emblem - the Tiger towards the brink of local extinction. In response tourists will increasingly seek out alternative and more environmentally pristine destinations.

The present paper describes the research and analyses undertaken towards the production of a new holistic SIP for the Park. It explains how the SIP aims both to preserve critical biodiversity and create significant positive economic and social impacts through sustainable tourism, and restorative land management and development, both within the Park and within its much wider zone of influence.

\section{Methods}

The present project was undertaken between 2012 and 2016 inclusive. The authors of this paper are specialist eco-masterplanners, landscape architects and ecologists. Note that while the authors are UK-based, each had worked on various other projects in Malaysia and south-east Asia prior to the present project and so were already broadly familiar with the environmental and socio-economic issues prevailing at the study Site. Supporting Project Team members were all Malaysia-based and included consultants with specialisms in architecture, planning, transport, economics, tourism and anthropology.

The assessment of baseline environmental conditions within the Park and its hinterland was undertaken on the basis of: 
- Field visits; four separate visits by the authors and many additional visits undertaken by other Project Team members during 2013 and 2014, from which information was collated on -

- The type and distribution of habitats / species and associated ecosystem services.

- Management practices.

○ Anthropogenic threats.

○ Visitor facilities and potential future requirements.

- Socio-economic and cultural status of indigenous and other local communities.

- Meetings and workshops; these were held with Governing officials from both states, Johor National Park Corporation, Pahang State Forestry Department, NGOs (including local Wildlife Conservation Society [WCS]), Jakun Orang Asli villagers and tour guide representatives.

- Desk-based records and publications.

\section{Geographical overview}

Being located near the equator Endau Rompin has an equatorial climate characterized by high temperatures (annual mean $27^{\circ} \mathrm{C}$ ), rainfall (c. 3,400mm) and humidity $(85 \%)$ throughout most of the year. The Park covers $807 \mathrm{~km}^{2}$, which is approximately the size of Singapore $\left(719 \mathrm{~km}^{2}\right) ; 489 \mathrm{~km}^{2}$ being on the Johor side and $318 \mathrm{~km}^{2}$ on the Pahang side.

The Park's topography is relatively hilly and locally quite precipitous, including steep-sided cliffs and deep gorges. The low ground and hills in the east rise to a more mountainous west, which includes Endau Rompin's highest peak, Gunung Besar $(1,036 \mathrm{~m})$. The Park's name is derived from its two key rivers Sungai Endau (Figure 3) and Sungai Rompin, which tumble over many spectacular waterfalls and rapids on the western side (Figure 4).

The Park is at its nearest point c. $27 \mathrm{~km}$ from Peninsula Malaysia' east coast and the South China Sea, the two being separated by a low coastal plain with extensive oil palm and latex timber clone plantations. Offshore are the Mersing Islands, otherwise 


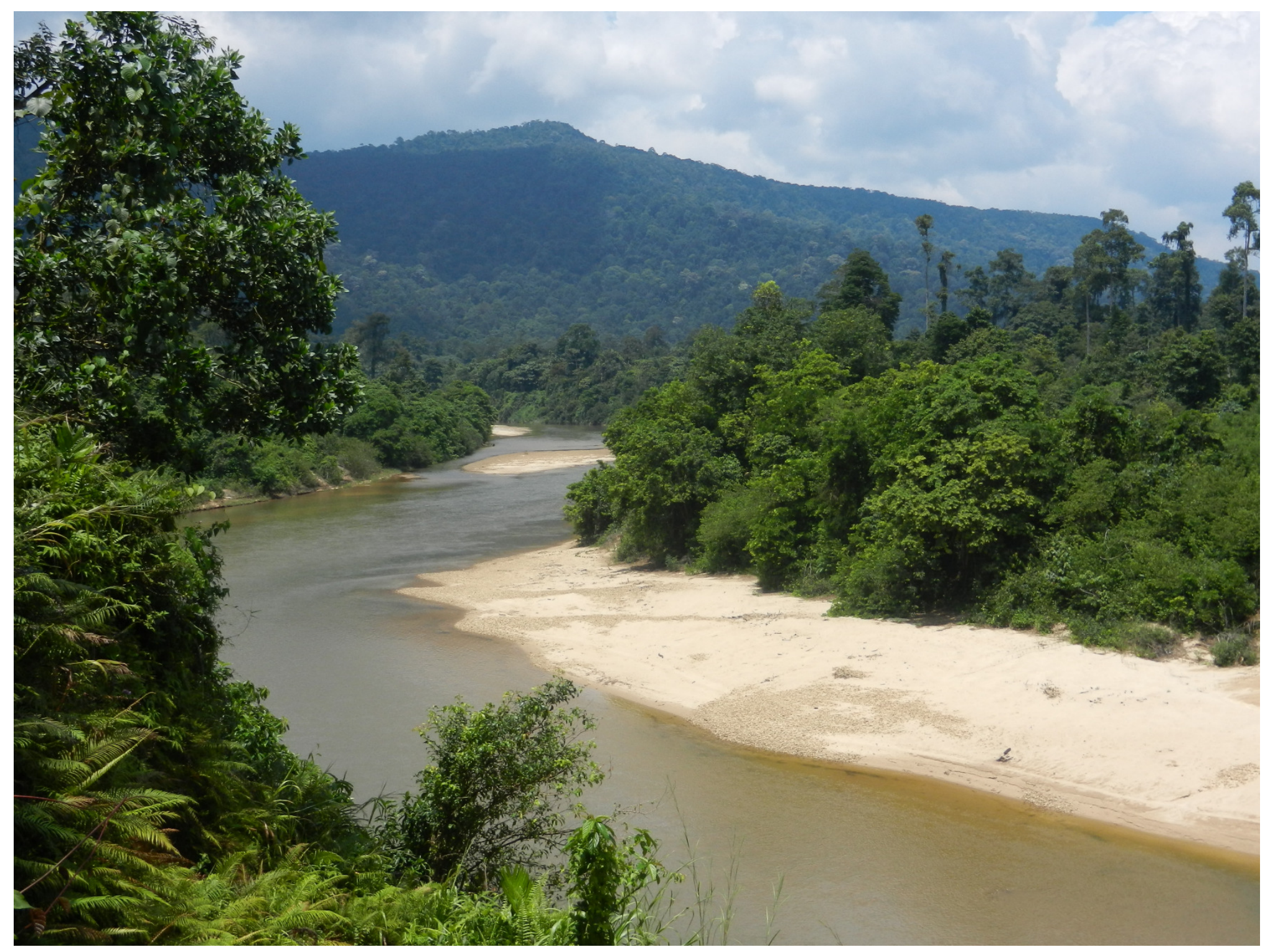

Figure 3. Sungai Endau near Kampung Peta on the eastern margin of Endau Rompin National Park 


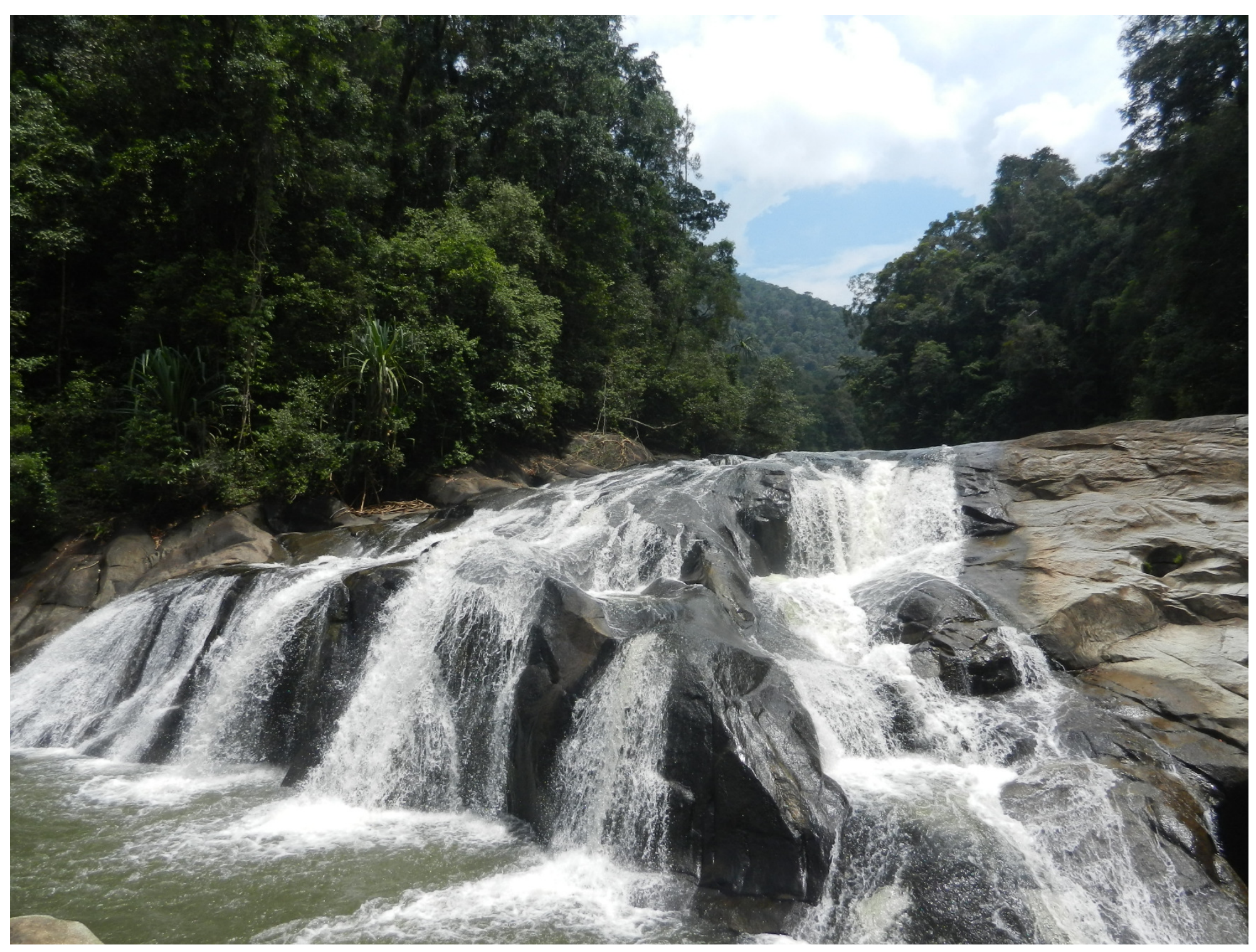

Figure 4. Spectacular Upeh Guling waterfalls, Endau Rompin National Park 
known as the Seribuat Archipelago, which comprise 62 islands and Marine Park protected coral reefs and other notable marine habitats.

\section{Flora and fauna}

The climax vegetation of the Park, as well as lowland Peninsula Malaysia more generally, is tropical evergreen dipterocarp rainforest (Whitmore, 1990). The Park also includes unusual hillside heath and padang forest formations associated with sandstone outcrops and plateaus (Wong, Saw \& Kochummen, 1987). While the majority rainforest within the Park is considered virgin, most forest extending beyond the Park boundary is secondary and is becoming increasingly fragmented due to expanding oil palm and rubber plantations.

In spite of various anthropogenic threats (discussed below), the Park still supports one of the most notable faunal assemblages remaining in Peninsular Malaysia (Nor et al. 1995). The Park's mammal fauna (60 species) includes most of Malaysia's larger carnivores and ungulates and at least 21 species of bat. Malayan Tapir Tapirus indicus, Asian Elephant Elephas maximus, Sambar Deer Rusa unicolo, Wild Pig Sus scrofa and Barking Deer Muntiacus muntjak are the most common large mammal species in the Park. The Park contains populations of five of the seven species of monkey in Peninsular Malaysia - Dusky Leaf Monkey Presbytis obscura, Silvered Leaf Monkey Presbytis cristata, Bearded Langur Presbytis femoralis, Long-tailed Macaque Macaca fascicularis, Pig-tailed Macaque Macaca nemestrina; and two of Peninsular Malaysia's three Gibbons - White-handed Gibbon Hylobates lar and Dark-Handed Gibbon Hylobates agilis. Cat species include Tiger, Leopard Panthera pardus, Clouded Leopard Neofelis nebulosa, Asiatic Golden Cat Catopuma temminckii, Leopard Cat Prionailurus bengalensis and Marbled Cat Pardofelis marmorata (Gumal et al., 2014).

A total of 253 species of birds have recorded in Endau Rompin (Chin, 2000; Davison, 1987). The Park, together with the Lenggor and Sedili Forest Reserves to the south-east and the Rompin mangroves to the east, have been designated as an Important Bird Area by Birdlife International. Endau Rompin also includes at least one caecilian, 51 frog species, 43 snakes, 39 lizards, and six turtles (Wood, Grismer \& Youmans, 2008). 


\section{Indigenous communities}

The indigenous people of Peninsular Malaysia are referred to as the Orang Asli (meaning Original People), and are estimated to number 150,000, which represents approximately $0.5 \%$ of the Malaysian population (Gomes, 2008). The Orang Asli consist of three principal ethnic groups, the Negrito (northern region), Senoi (middle region), and Proto-Malay (southern region). The Jakun are a subgroup of the ProtoMalay and are dominant in and around the Park.

The Park's principal Jakun community reside at Kampung Peta (kampung being Malay for village) and number approximately 220, constituting $2 \%$ of the entire Orang Asli population in Johor. While they have adopted various modern technologies, in other ways they still adhere to ancestral / animistic beliefs and taboos, and to varying degrees practice traditional lifestyles, including fishing, hunting, farming, and trading of forest products (Jamiran \& Wee, 2014; Sam \& Wee, 2014; Sabran, Mohamed \& Bakar, 2016). The younger generation are less interested in preserving their cultural heritage and are increasingly seeking education, contemporary lifestyles and general socioeconomic improvement beyond their communities. The Jakun benefit directly from the Park through selling handicrafts, homestay and tour guide services.

\section{Existing nature-based tourism and access}

The nearest major airports to Endau Rompin are in Kuala Lumpur, Singapore, Johor Bahru and Tioman, the latter being in the Mersing Islands. The journey to the Park's satellite towns - Mersing (on the coast to the east), Rompin (on the coast to the northeast), Kahang (south), Kluang (south) and Bekok (south) - typically takes four or more hours by car from Kuala Lumpur and Singapore along roads of reasonable quality. A further two hours is typically required to travel from the satellite towns to accommodation within the Park via roads in varying states of disrepair, although their poor condition does add to a feeling of venturing 'into the wild'.

Endau Rompin's attractions include its rich assemblage of flora and fauna, river journeys, rainforest walks, and the Jakun kampungs. The Park's nature-based tourism activities and attractions (including accommodation) are primarily based around two locations on the Johor side; Peta on the eastern edge of the Park and Selai near the south-western border. A boat service operated by local Jakun is available to transport visitors arriving at Peta deeper into the Park to the settlement of Kuala Jasin, from 
which hiking trails ascend to the spectacular Upeh Guling and Buaya Sangkut waterfalls and boulder pools. At Kinchin, which is the key destination and accommodation on the Pahang side of the Park, canoes can be hired to journey downstream over a series of minor rapids and across the border into Johor and on to Peta.

\section{Threats to sustainable tourism}

Endau Rompin is facing various pressures that threaten its long term ecological integrity and therefore also the potential for it to attain ECERDC's key objective of becoming a sustainable 'internationally recognised ecotourism destination'. These challenges are summarised as follows.

\section{Park Size, logging and land conversion}

The Park is too small for many species of mammalian macrofauna such as Tiger and Elephant to sustain long term viable populations. Small populations are threatened by reduced genetic diversity and an increased likelihood of population fluctuations leading to local extinction. Only when the Park's forest is combined with surrounding secondary forest, covering an area c.5,500 $\mathrm{km}^{2}$, is there sufficient habitat to support a viable Tiger population and other large mammalian species, though this also assumes that forests are appropriately managed and protected (Kawanishi et al., 2003; Wildlife Conservation Society, 2013) (Figure 5). Although there have been proposals to expand the Park, first recommended in 1994 and then again in 2000 (Danish Cooperation for Environment and Development [DANCED], 2000), no progress has been made. Furthermore, progress is slow in implementing the Government-endorsed Central Forest Spine Masterplan, which aims to reconnect isolated forest islands with core protected areas (including Endau Rompin) extending the length of Peninsula Malaysia (Maniam \& Singaravelloo, 2015). Note that the Central Forest Spine strategy and associated National Tiger Conservation Action Plan are considered crucial to the survival of Tigers in Malaysia.

Logging of forests and subsequent conversion of land to agriculture - usually vast tracts of oil palm and rubber monoculture - is continuing apace in the Park's hinterland (Chiew, 2009), and indeed more widely across Peninsula Malaysia (Yong, 2012). 


\section{$\pi$}

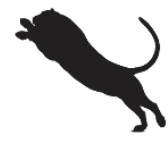

number of

individuals Endau
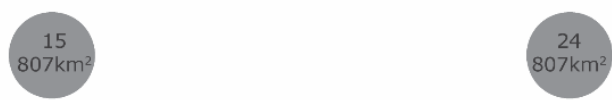

Area required to

support 50
individuals
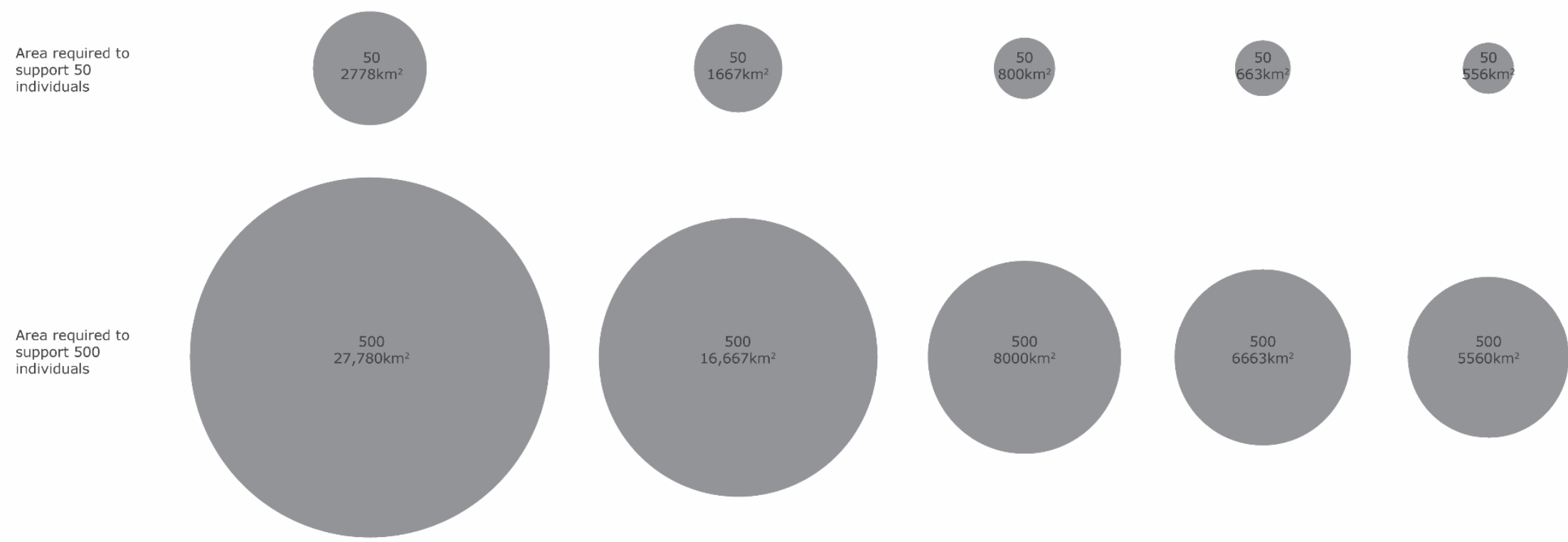

N.B. The above est

Figure 5. Habitat requirements to support viable populations of key macrofauna (N.B. for short-term survival - that is over the next few generations - the minimum number of breeding animals is assumed to be an effective population size of 50; for long-term survival, however, a minimum effective size of 500 individuals is recommended [Frankel and Soule, 1981]) 
Forest buffers along many river sections in Malaysia (including in the vicinity of the Park) are becoming increasingly degraded with various adverse environmental implications, including loss of riparian fauna; increased runoff leading to soil loss, river sedimentation, and agricultural pollution (including from untreated palm oil-mill effluent); and flash flooding (Gray, 2014). With respect to flooding, many towns and kampungs surrounding the Park are regularly affected, including Mersing, Segamat and Kluang (Ngah \& Othman, 2010; Gasper, 2013). Sediment loaded runoff works its way downstream and ultimately adversely affects sensitive marine habitats, including seagrass meadows off the coast of Mersing (Firdauz, Golingi \& Oliver, 2008) and even the coral reefs of the Mersing Islands (Association of Southeast Asian Nations / United States Coastal Resources Management Project [ASEAN / US CRMP], 1991). Although riparian buffer zones have some legal protection in Malaysia, much riverine deforestation occurred prior to the legislation, while subsequent to the legislation some land managers appear to have simply ignored regulations (Gray, 2014).

\section{Poaching}

In 1994 the Malaysian Nature Society predicted that Endau Rompin's Sumatran Rhinoceros Dicerorhinus sumatrensis population would survive for perhaps another 50 years given current rates of forest loss. This prediction however downplayed the significance of poaching. The Park's last Sumatran Rhinoceros was poached in 2003, just nine years later (Song Horng Liang, WCS, pers comm. 2013). Poaching has also been primarily responsible for accelerating the subsequent extinction of Rhino from all of Peninsular Malaysia and indeed continental Asia (Havmøller et al., 2016).

The Park's Tiger population is also seriously threatened by poaching. The Park may now support only 6-14 Tigers (Song Horng Liang, WCS, pers comm. 2013). While efforts are being made by JNPC to address the Tiger poaching risk in collaboration with WCS, unless anti-poaching enforcement measures are stepped up (combined with a concerted effort to implement the Central Forest Spine strategy) the Tiger could well be the next high profile extinction. This would be disastrous not only from a conservation perspective, but also a major symbolic loss in terms of the Park's appeal to the international ecotourism market. 


\section{Federal versus State}

Whilst policies are made at the Federal level in Malaysia, the implementation of actions pertaining to land-use and natural resource management occurs at the State level (DWNP, 2008; Tan, 2008; Ngah \& Othman, 2010; Maniam \& Singaravelloo, 2015). Currently there appears to be little movement to transpose key Federal nature conservation legislation/policies, including the Central Forest Spine strategy, into state law. Without effective State-level support and legislation it is likely that lucrative logging concessions will continue to be issued in sensitive forest areas just outside of the Park such as Sungai Mas, which was initially identified at the Federal level as being a vital link in the Central Forest Spine chain (Chiew, 2009; Maniam \& Singaravelloo, 2015).

\section{Management and ranger numbers}

Management and ranger numbers have long been inadequate for the largest lowland rainforest in the lower half of Peninsular Malaysia, particularly given the challenges described above and below. In this regard note that the Management Plan produced by DANCED in 2000 observed 'it is clear that the Endau Rompin (Johor) National Park falls well below the recommended international norm'. The Park's Johor side, at that time, had approximately 12 Park rangers, a figure that remained roughly constant to the time of the present study. The Pahang side was found to be similarly poorly resourced. Note that the World Conservation Union (IUCN) recommends that national parks and wildlife sanctuaries should have one forest ranger for every 1,000 ha of land with protected area status, meaning that Endau Rompin should have at least 80 rangers. It also seemed evident from discussions in and around the Park that there is limited dialogue or joined-up management between Park authorities on either side of the State border.

\section{Road construction}

Data collected by Department of Wildlife and National Parks (DWNP) Peninsular Malaysia between 1991 and 2003, showed that the construction of Malaysia's NorthSouth Highway (completed in 1994) effectively eliminated Tiger habitats west of the road (DWNP Peninsular Malaysia, 2008). New roads fragment Tiger habitat and 
disrupt their behavioural patterns, facilitate the movement poachers and logging/agricultural activities into formerly inaccessible areas, and lead to increased road casualties (Fehlberg, 1994; WWF, 2017). Concerns have therefore been expressed relating to new road construction proposals for areas surrounding Endau Rompin, most notable of which is the Selendang - Selancar east-west highway, which will ultimately encompass the Park's northern margins.

\section{Visitor numbers}

Although Park visitations have been steadily increasing, numbers are still considered very low and revenues negligible given the Park's size and the performance of comparable sites. Many existing facilities are in various states of disrepair and incapable of currently attracting high-paying visitors. Satellite towns barely recognise the Park's existence; the 'Park, what Park?' phenomenon.

\section{Local communities}

The Jakun community appears beleaguered and losing its self-esteem and cultural identity (Jamiran \& Wee, 2014; Mohd Sam \& Seow, 2014). Jakun communities have suffered recent flooding disasters (Jamiran \& Wee, 2014); are regularly accused by Park authorities of poaching and deforestation (Johor National Park, pers comm. 2013); and in many cases lack secure land tenure and thus face threats of eviction by local authorities (Jonas, Roe \& Makagon, 2014).

Encroachment of plantations and kampungs into the Park and surrounding forest by the Jakun and others is also leading to increased human-elephant confrontations, particularly where Elephants cause crop damage (Ying, 2014; Maniam \& Singaravelloo, 2015).

\section{Rainforest to Reef - A new vision for a sustainable future for Endau Rompin and its hinterland}

In contrast to the single habitat or species approach to management, landscapescale/ecosystem-based management is concerned with the 'complex interactions between humans and the living and non-living environment over multiples scales in space and time’' (Clarke \& Jupiter, 2010). This holistic approach places particular 
emphasis on the linkages between land and sea; the implications of human activities; conservation of ecosystems and their functions; and integration of ecological, socioeconomic and governance perspectives.

In the face of Endau Rompin's multiple complex and overlapping pressures, such a landscape-scale approach must be implemented: to protect and enhance the Park's biodiversity and that of its vital hinterland; to deliver sustainable socio-economic development; and to provide a high quality visitor experience. In this regard our studies envisage the Park:

- Expanding in size to reduce pressure on key ecological resources, and also to incorporate any remaining contiguous primary forest and as much secondary forest as possible; thereby creating capacity to support viable populations of Tiger and other macrofauna.

- Recovering ecological integrity through restorative management, improved ranger services (crucially including effective anti-poaching measures), and the creation of robust ecological linkages with other natural/semi-natural habitats across this wider area.

- Becoming the key feature in a wider strategic development zone on Malaysia's east coast, stretching eastwards from the Park's western mountaintops, beyond the Park boundary and across the coastal plain to the South China Sea, and then offshore to the reefs and waters of the Mersing Islands; a wider area perhaps five times or more the size of the Park.

- Being managed and branded in combination with other attractions within this expanded zone, providing a more varied package of experiences and revenue streams, and thereby appealing to a wider tourism market.

The authors have suggested that the proposed wider strategic development zone be referred to as Malaysia's new 'Rainforest to Reef Region', an appellation which has now been adopted for the area by ECERDC (2016) (Figure 6). Within this wider landscape visitors are envisaged as being able to experience a diverse range of nature inspired experiences and activities within the space of just a few days. These might range from snorkelling among the Mersing Islands' spectacular coral reefs; to relaxing on the soft sandy beaches between the coastal towns of Mersing and Rompin; to kayaking serenely along the Park's jungle-lined rivers. 


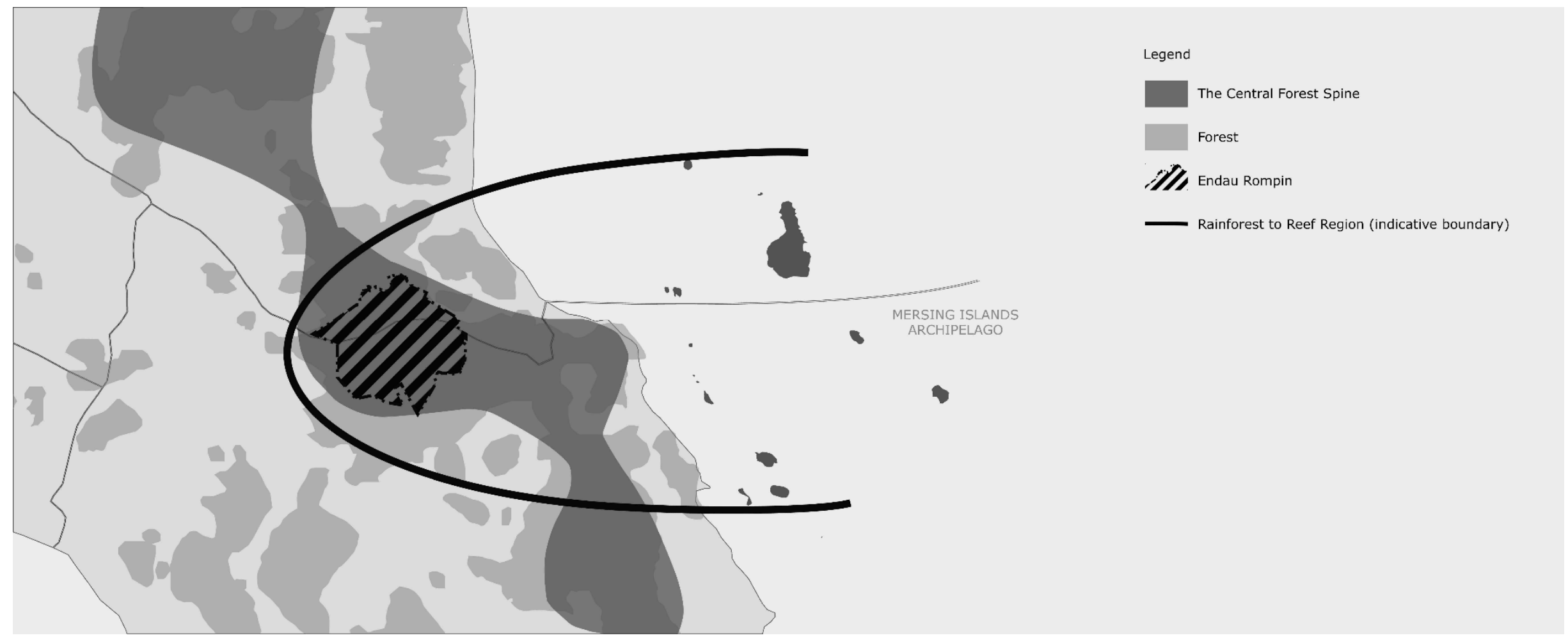

Figure 6. Malaysia's new 'Rainforest to Reef Region' is envisaged as a wider strategic development zone based around ecotourism, stretching from the Park's Western boundary, across the coastal plain to the South China Sea, and then offshore to the Mersing Islands 
'Rainforest to Reef' is intended to be a distinctive eco-inspired brand affording the Park and its hinterland a clear regional identity, distinguishing it from alternative destinations that provide a more limited range of natural and visitor attractions. This approach is very much in accordance with conclusions reached by others asserting that focus on the specialist eco-niche tourism market alone will almost certainly fail to generate the revenue required to significantly impact on the regional economy (Lumsdon \& Swift, 1998; Weaver, 1999). Rather the new Rainforest to Reef Region would also target more casual nature tourism, including sun, sea and sand tourists, who might attend organised tours as a diversion from or as one component of a multipurpose trip.

\section{Rainforest to Reef - zoning}

Targeting a broader tourism market, however, must not compromise the integrity of core conservation areas. In many ecologically pristine areas it is asserted that any introduction of nature tourism will have an adverse environmental effect, which in effect implies a carrying capacity of zero (Batta, 2002). In turn this has led to the Limits of Acceptable Change concept (Stankey et al., 1985). However, far from accepting an acceptable level of environmental degradation, others contend that true ecotourism should tackle head-on this paradoxical relationship with the environment and achieve a net gain for biodiversity (Blangya \& Mehtac, 2006; Koens, Dieperink \& Miranda, 2009). Careful zoning of activities and appropriate visitor management, crucially combined with reinvestment of revenue accrued from ecotourism into habitat restoration, can achieve real ecological and socio-economic gains.

Within the new Rainforest to Reef Region the creation of the following major zones and destinations are envisaged (Figure 7):

- Core Conservation Area; covering the entire Park and as much adjoining forest as possible.

- Community Forest Zone; promoting sustainable forest management and lowimpact development.

- Sustainable Agroforestry Zone; promoting sustainable agriculture, and also including new nature-based tourism attractions for visitors moving between the coast and Park. 


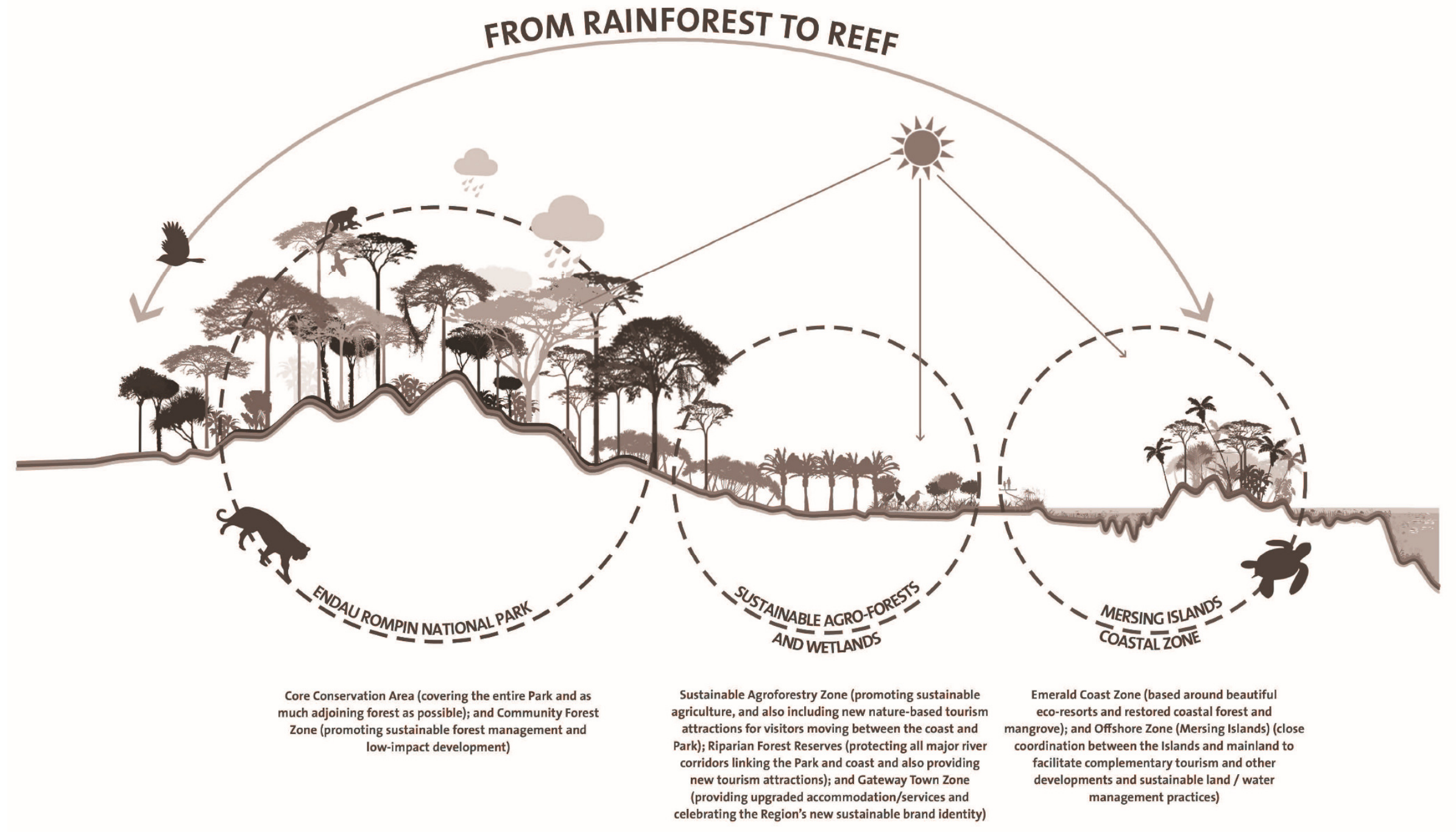

Figure 7. From Rainforest to Reef - zoning strategy 
- Riparian Forest Reserves; protecting all major river corridors linking the Park and coast and also providing new tourism attractions in themselves.

- Emerald Coast Zone; based around beautiful eco-resorts and restored coastal forest and mangrove.

- Gateway Town Zone; providing upgraded accommodation/services and celebrating the Region's new sustainable brand identity.

- Offshore Zone (Mersing Islands); close coordination between the Islands and mainland to facilitate complementary tourism and other developments and sustainable land/marine management practices.

These proposed zones are described in more detail below, though within the scope of the SIP project it has only been possible to consider zoning opportunities at a relatively conceptual level. Further work is required to confirm the viability of proposals and to refine zoning boundaries and goals.

\section{Core Conservation Areas}

Any development within or near the Park must not compromise the fundamental conservation objectives of the Park. The entire Park is therefore envisaged as a Core Conservation Zone to be afforded strict protection. Within this Core Conservation Zone a limited number of linear recreational corridors would be provided, concentrated around existing resorts and attractions. These would cater for two key markets: true ecotourists (whom generate moderate revenues but are considered vital for the Park's profile); and high-margin / luxury nature tourists, paying for the privilege of staying close to the prime wildlife areas (impact carefully managed to a low-level through design and control of numbers). Compatible activities within the Park would include wildlife watching and study, guided trekking and nocturnal walks, and controlled kayaking and white-water rafting. In keeping with earlier recommendations (DANCED, 2000), the Park boundary should also be extended to incorporate all remaining primary forest and as much secondary forest as can be negotiated.

\section{Community Environment Zone}

Traditionally this zone would be referred to as the Park's Buffer Zone. However, experience from many developing countries has shown that the term 'Buffer Zone' can 
be self-defeating, implying a top-down approach to development and planning where local communities come second place to nature conservation interests (Lynagh \& Urich, 2002). Key to the success of this zone would be the need to set up special synergies between inhabitants, businesses and the Park to ensure that there is a culture of preservation for collective benefit. Mechanisms could take the form of a variety of incentives and tax breaks for forest-friendly and sustainable activities, perhaps under Reduced Emissions from Deforestation and forest Degradation programme (REDD+; Maniam \& Singaravelloo, 2015). The Community Environment Zone would ideally encompass all adjacent areas of Forest Reserve remaining outside of the expanded Park boundary, and also an appropriate buffer around each of these. Both the Park and the Community Environment Zone should integrate with the Government's Central Forest Spine initiative, identifying and protecting important Tiger habitats outside of the Core Conservation Zone. Johor and Pahang could then become the first states in Malaysia to enshrine this vital national policy into state law, bolstering their reputations as leading states promoting nature conservation and sustainable tourism.

Tourism and conservation strategies tend to fail if indigenous and other local communities obtain no meaningful and sustainable benefit (Eagles, Bowman \& Tao, 2001). The Community Environment Zone concept therefore envisages concessions and permissions to harvest forest products being granted to Jakun communities in return for commitments to implement sustainable practices and support (and joining-up with wherever possible) the expanded Park ranger service. This zone would also include the establishment of various cultural heritage attractions that would be integrated into existing Jakun kampungs rather than kept separate. Integration of the two should promote establishment of homestay, local restaurants and other services, engender pride in kampung appearance, and generally encourage more environmentally responsible behaviour.

\section{Sustainable Agroforestry Zone}

As discussed Government and park eco-tour operators report that many visitors react negatively on their arrival experience to the National Park, which typically involves long journeys travelling through large tracts of oil palm and rubber plantation. All oil palm plantation owners within the Rainforest to Reef Region would be strongly encouraged to convert to Roundtable on Sustainable Palm Oil (RSPO) standard, or 
preferably more stringent environmental land management practices. Certainly no consideration should be given to adopting more relaxed standards that have recently been supported by elements within the industry (Rainforest Action Network, 2011).

This zone could include a Rainforest Adventure Park (or parks) to provide recreational opportunities for locals as well as the middle/lower margin high volume tourism market. While activities in the Rainforest Adventure Park would need to herald the Park and its assets, due to its less sensitive context it would be able offer a much greater variety of adventure experiences than would be possible within the Park boundary. Such activities might include 4-wheel drive and amphibious vehicle safaris, fishing, assault and adventure courses, scout camps, orienteering, mountain biking, water sports etc. Successful examples of these sort of activities in less sensitive hinterlands of national nature reserves exist elsewhere, e.g. Daintree, Australia.

\section{Riparian Forest Reserves}

The Rainforest to Reef concept envisages Riparian Forest Reserves being created along all major rivers extending between the Park and South China Sea coastline, i.e. Sungai Endau, Sungai Rompin, Sungai Anak Endau and Sungai Pontian. Protecting and expanding riparian forest would strengthen habitat connectivity between the Park and existing coastal forests (including mangrove), and would also reduce soil erosion, sedimentation, flooding and pollution. The creation of Riparian Forest Reserves, as well as reforestation elsewhere, would all form part of a wider sustainable and integrated river catchment strategy (Ngah \& Othman, 2010). Riparian Forest Reserves would also become ecotourism attractions in themselves (including evening fire-fly displays), and where practical, provide scenic alternative routes of access into the Park.

\section{The Emerald Coast Zone}

In Costa Rica beautiful beaches have been marketed as key assets to attract large numbers of sun, sea and sand tourists, many of which then decide to go on short excursions into local rainforest areas (Lumsdon \& Swift, 1998; Weaver, 1999). Similarly, creating high quality eco-resorts and improving the quality of beaches within the proposed Rainforest to Reef Region is fundamental for tapping into this particular market. At present the coastal resorts appear to significantly underperform. A Blue Flag award system would be encouraged, similar to that used in many other countries, 
whereby beach quality is regularly assessed in terms of environmental health. Any award system must also seek to protect and restore coastal forest/mangrove and adjacent marine habitats. It is critical though that planning regulations ensure that intensive, chaotic and environmentally damaging resort development, reminiscent of much of the coastline of the European Mediterranean and Costa Rica's 'Gold Coast' is avoided (Lumsdon \& Swift, 1998; Driscoll et al., 2011).

\section{Offshore (Mersing Islands) Zone}

Tropical islands represent many people's dream of the perfect holiday, and it is not surprising that island tourism in Malaysia has been rapidly growing for the last few decades (Mosbah \& Khuja, 2014). By incorporating the Mersing Islands within the Rainforest to Reef branded attraction, there is great potential for encouraging visitors initially attracted by an island vacation to also go on excursions to various new mainland attractions, including to Endau Rompin. Any concurrent increase in visitor numbers to the Mersing Islands would need to be closely monitored and regulated to avoid exacerbating environmental impacts on marine habitats that are already becoming apparent (Praveena, Siraj \& Aris, 2012). The creation of the Rainforest to Reef Region would though be expected to promote better coordination between the various tiers of government and land managers, including a more joined-up approach to management of both terrestrial and marine natural resources.

\section{Gateway Towns}

Visitors to national parks also spend a relatively substantial amount of time and money eating, sleeping, parking, shopping, and sightseeing just outside in what are known as 'Gateway towns'. This spending in turn can generate significant employment and tax revenues. Endau Rompin's satellite towns barely recognise the Park's existence and so gain little financial reward from their potentially financially lucrative context. The Rainforest to Reef concept envisages these towns being marketed with the Park as a single destination. These Gateways should celebrate the Park, as well as the Mersing Islands and wider Rainforest to Reef Region, through signage, visitor centres, tour promotions and school education. 


\section{Rainforest to Reef - a mechanism for reduce poaching}

It is imperative that the potentially catastrophic poaching problem is properly tackled as part of Rainforest to Reef. Increased focus on nature-based tourism should lead to more regular patrolling of the Park (and patrols within surrounding forest) by rangers and scientific research teams, and also increased tourist visits, all of which would mean more 'eyes on the ground' to observe and report suspicious and illegal behaviour. Providing the Jakun and other local communities with alternative and legitimate sources of income would also reduce their propensity to engage in local hunting and forest clearance, as they increasingly recognise how these activities threaten their new career opportunities.

Clearly, given the scale of the problem, other measures would also need to be taken, critically including a dramatic increase in ranger numbers (to at least 80 in keeping with IUCN guidance but preferably to 100). This must be combined with public education programmes including within schools. Note that within the Western Forest Complex of neighbouring Thailand, Tiger numbers have rebounded in response to 'relentless, systematic, boots-on-the-ground patrolling [including by Thailand's wellarmed and trained Smart Patrol unit] and monitoring of both tiger and prey in those sites assessed as harbouring realistically defensible core breeding populations of tigers' (Alexander, 2011). Note though that any armed response to poaching must be proportionate to avoid recent controversies experienced by parks such as Kaziranga in India (Rowlatt, 2017).

\section{Rainforest to Reef - the economic imperative}

The Rainforest to Reef Region would not simply promote ecotourism but rather would have a much wider remit, encouraging green technologies and businesses as well as sustainable agricultural practices. Where better to locate a new sustainable enterprise in Peninsular Malaysia than in the new Rainforest to Reef Region. Some parallels can be drawn between the Rainforest to Reef concept and the remodelling of Singapore as the 'City of Gardens and Water'. The City of Gardens and Water approach, which promotes of greenery and sustainable living, was described by Singapore's former Prime Minister, Lee Kuan Yew, as fundamental to the differentiation of the city state from its competitors, which in turn has attracted substantial foreign investment and talent to the nation (Wassenhove, 2013). 


\section{Administration}

While the Rainforest to Reef Region would remain under the jurisdiction of Johor and Pahang, the concept envisages the establishment of a Transboundary Executive to harmonise policies and legislation across the new cross-border region, i.e. creating 'two States one solution'. All vested interests would be represented on the Executive, although the remit would be clear, to promote sustainable economic, social and environmental development. A new planning/tax mechanism would also need to be put in place to direct a proportion of revenue generated in the hinterland, accrued on the back of the Park and attractions within the wider Rain Forest to Reef Region, towards habitat restoration and management.

The Rain Forrest to Reef concept envisages the following roadmap for establishing the administrative structure:

(1) Cross-border Steering Committee set up to establish objectives for the sustainable management of the Park and wider Rainforest to Reef Region.

(2) This committee would then establish stakeholder committees and partnerships, including representatives from forestry, plantation owners, NGOs, local communities etc.

(3) Capacity assessments would be undertaken and gaps addressed.

(4) Public/business education programme would be developed to create support for the new Rainforest to Reef Region.

(5) Necessary funding for Rainforest to Reef implementation would be identified, secured and allocated.

(6) Guidelines on development, ecotourism and agriculture would be produced to promote sustainable practices within the region.

(7) Effective cross-border governance and administration would be established.

(8) The Rainforest to Reef Region would be formally integrated into regional, state and local government planning policy and legislation.

\section{Conclusions}

While the Malaysian Government sought an ecotourism and environmental management framework specifically for Endau Rompin National Park, it quickly became evident to the authors that any hope of achieving meaningful socio-economic 
and environmental gains for the Park and the wider region could not be realised without adopting a landscape-scale approach to nature conservation, ecotourism and development more broadly. The conceptual solution arrived at is for Endau Rompin to become the core attraction within a much wider ecologically enhanced landscape that we have branded as Malaysia's new Rainforest to Reef Region, stretching from the Park's western extremities, to the beaches and reefs of the local coast and Mersing Islands.

The creation of the Rainforest to Reef Region is intended to:

- Better connect the natural assets of the region and offer a range of distinctive destinations for amenity, environmental education and enjoyment, in a way that restores, enriches and protects the environment for future generations.

- Provide a unique and more diverse offer of destinations, including world-class beaches and reefs, through to a range of nature-based experiences, catering sustainably for both mass and niche tourist markets.

- Establish an integrated cross-border (Johor and Pahang) approach to the management of natural resources and tourism, enabling the two states to share scarce resources and environmental standards, benefit from economies of scale, and strengthen relations.

- Provide multiple economic, educational, cultural and environmental benefits for the communities of the local area and wider region, by offering commercially viable and sustainable alternatives to existing environmentally damaging practices such as poaching and oil palm/rubber plantations.

- Provide a foundation for the sustainable protection and enhancement of the Park as an internationally important rainforest, supporting viable populations of Tiger and Elephant and high biodiversity across all biotic groups.

- Become a venue of international status, influencing sustainable tourism development throughout South-east Asia and beyond.

ECERDC has encouragingly taken the first step towards this vision by integrating the strategy into its policy objectives and also announcing to the Malaysian media that 'Mersing and its surrounding islands are well positioned to become a great eco-tourism attraction, in accordance with the Rainforest to Reef $(R 2 R)$ concept. The $R 2 R$ concept seamlessly links all products, assets and development, from the Endau- 
Rompin National Park to world-class beaches, islands and reefs off the coast of Mersing' (New Straits Times, 2016).

Perhaps though it will be the fate of the region's Tiger population which will be the defining test as to whether or not the new Rainforest to Reef Region will become merely a brand without substance, or develops into a truly sustainably managed tourism destination of the highest international calibre. If the Tiger can be saved from the brink of local extinction it will be the clearest evidence that a holistic/landscape-scale approach to natural resource management and tourism is being implemented; entailing effective control of poaching; forest restoration; and protection of riverine and marine environments. In turn a healthier and more biodiverse landscape will attract many more tourists, benefitting the Jakun and other local communities, as well as the wider regional economy.

\section{Acknowledgements}

We are very grateful to ECERDC for commissioning the original SIP study and for the support of Peers Consult which coordinated the wider SIP study.

\section{Disclosure statement}

The authors are not aware of any potential conflict of interest related to the publication of the present paper.

\section{References}

Alexander C. 2011. A cry for the tiger. National Geographic, December 2011: 62-87.

ASEAN / US CRMP. 1991. The coastal environmental profile of South Johore,

Malaysia. Manilla: International Center for Living Aquatic Resources Management.

Augeri DM. 2005. Biogeographic Ecology of the Malayan Sun Bear. International Bear News, 14, $25-26$.

Batta, RN. 2002. Tourism and the environment: A quest for sustainability. New Delhi: Indus Publishing. 
Blangya S \& Mehta H. 2006. Ecotourism and ecological restoration. Nature Conservation Journal, 14: 233-236.

Chiew H. 2009, $31^{\text {st }}$ March. Broken spine. The Star Online. Available at http://www.thestar.com.my/data/archives/2013/06/21/04/49/broken-spine/

Clarke P \& Jupiter S. 2010. Principles and practice of ecosystem-based management: A guide for conservation practitioners in the tropical western Pacific. Suva: Wildlife Conservation Society.

Clements R, Rayan DM, Zafir AWA, Venkataraman A, Alfred R, Payne J, Ambu L \& Sharma DSK. 2010. Trio under threat: Can we secure the future of rhinos, elephants and tigers in Malaysia? Biological Conservation, 19, 1115 - 1136.

Commission on Growth \& Development 2008. The growth report: Strategies for sustained growth and inclusive development. Washington DC: World Bank.

Daintree Discovery Centre 2015. About the Daintree rainforest. Available at http://discoverthedaintree.com/daintree-rainforest-6/

DANCED 2000. Revised and updated management and development plan for the Endau-Rompin National Park (Johor). Copenhagen: The Nature Education and Research Centre.

DWNP Peninsular Malaysia. 2008. National tiger action plan for Malaysia 2008-2020. Kuala Lumpur: DWNP.

Driscoll L, Hunt C, Honey M \& Durham W. 2011. The importance of ecotourism as a development and conservation tool in the Osa Peninsula. Washington, DC: Costa Rica Center for Responsible Travel.

Eagles PFJ, Bowman ME \& Tao TC. 2001. Guidelines for tourism in parks and protected areas of East Asia. Cambridge: IUCN.

ECERDC 2016. Economic clusters: Tourism. Available at http://www.ecerdc.com.my/en/economic_post/taman-negara-endau-rompin/ 
The Economist 2016. Malaysia: Government has big tourism plans for 2016. Available at

http://country.eiu.com/article.aspx $?$ articleid=864005670\&Country=Malaysia $\&$ topic $=E c$ onomy

Fehlberg U. 1994. Ecological barrier effects of motorways on mammalian wildlife - an animal protection problem. Deutsche Tierarztliche Wochenschrift, 101: 125-129.

Firdauz SN, Golingi T \& Oliver M. 2008. Detailed environmental impact assessment and hydraulic studies for the proposed Mersing Laguna reclamation. Kota Kinabalu: DHI Water \& Environment.

Frankel OH \& Soulé ME. 1981. Conservation and evolution. Cambridge: Cambridge University Press.

Gasper DT. 2013. Flash floods in Mersing and Segamat, villagers moved to relief centres. The Star Online. Available at http://www.thestar.com.my/news/nation/2013/12/02/johor-floods/

Gomes AG. 2008. The Orang Asli of Malaysia. International Institute for Asian Studies, 35: 10 .

Gray C. 2014. Corridors and buffers: Claudia Gray on riparian zones in Malaysia and across the world. The Freshwater Blog: The Voice of Freshwater Life. Available at https://freshwaterblog.net/2014/12/22/corridors-and-buffers-claudia-gray-on-riparianzones-in-malaysia-and-across-the-world/

Gumal M, Abu Bakar M, Mohd Nawayai Y, Horng LS, Lee, BPY, Chee Pheng L, Hasnizam H, Kong D, Magintan D, Ten Choon Yong, D, Ahmad Zulfi Z, Azima A, Khalid N, Thai PY, Voon M, Cheong Fook Meng F, \& Ng, S. 2014. Small-medium wild cats of Endau Rompin landscape in Johor, Peninsular Malaysia. CAT News Special Issue, 8: 10-18.

Havmøller RG, Payne J, Ramono W \& Ellis S. 2016. Will current conservation responses save the critically endangered Sumatran rhinoceros Dicerorhinus sumatrensis? Oryx, 50: 355-359. 
Hedges L, Lam WY, Campos-Arciez A, Rayan DM, Laurance WF, Latham CJ, Saaban, S \& Clement GR. 2015. Melanistic leopards reveal their spots: Infrared camera traps provide a population density estimate of leopards in Malaysia. Journal of Wildlife Management, 79: 846 - 853.

Koens JF, Dieperink, C. \& Miranda, M. 2009. Ecotourism as a development strategy: Experiences from Costa Rica. Environment, Development and Sustainability, 11: 12251237.

Jamiran MNS \& Wee ST. 2014. The environment of Kampung Peta. International Journal of Conceptions on Management and Social Sciences, 2: 2357 - 2787.

Jonas HD, Roe D \& Makagon JE. 2014. Human rights standards for conservation: A rights-based analysis and set of options to promote ethical conservation. London: IIED.

Kawanishi K, Hawa YS, Kadir AH \& Rahmat T. 2003. Distribution and potential population size of the tiger in Peninsular Malaysia. Journal of Wildlife Parks (Malaysia), 21: 29-50.

Kawanishi K \& Sunquist ME. 2004. Conservation status of tigers in primary rainforest of Peninsular Malaysia. Biological Conservation, 120, 329 -344.

Lumsdon LM \& Swift JS. 1998. Ecotourism at a crossroads: The case of Costa Rica. Journal of Sustainable Tourism, 6: 155-172.

Lynagh FM \& Urich PB. 2002. A critical review of buffer zone theory and practice: A Philippine case study. Society and Natural Resources, 15: 129-145.

Maniam A \& Singaravelloo K. 2015. Impediments to linking forest islands to Central Forest Spine in Johor, Malaysia. International Journal of Social Science and Humanity, 5: 2015.

Maps of the World. 2016. Top 10 tourist destinations in the world. Available at http://www.mapsofworld.com/world-top-ten/world-top-ten-tourist-destination.html

Mohd Sam SA \& Seow TW. 2014. Practice cultural of Orang Asli Jakun at Kampung Peta. International Journal of Conceptions on Management and Social Sciences, 2: 2630. 
Mosbah A \& Khuja MSAA. 2014. A review of tourism development in Malaysia. European Journal of Business and Management, 6: 1-9.

Ngah MSYC \& Othman Z. 2010. Water catchment management: A Malaysian perspective. Global Journal of Environmental Research, 4: 34-39.

Nor BM, Kassim H, Suri S, Othman S. \& Abdullah MT. 1995. A Survey on the distribution of large mammals in Endau Rompin State Park, Johor. The Journal of Wildlife and Parks, (Malaysia), 14: 16-25.

PEMANDU. 2010. Economic transformation programme: A roadmap for Malaysia. Putrajaya: PEMANDU.

Praveena SM, Siraj SS \& Aris AZ. 2012. Coral reefs studies and threats in Malaysia: a mini review. Reviews in Environmental Science and Bio/Technology, 11: 27-39.

Queensland Parks \& Wildlife Service. 2016. Queensland ecotourism plan 2016-2020. Brisbane: Department of National Parks, Sport and Racing.

Rayan DM \& Linkie M. 2015. Conserving tigers in Malaysia: A science-driven approach for eliciting conservation policy change. Biological Conservation, 184: 18-26.

Rowlatt, J. (2017). Kaziranga: The park that shoots people to protect rhinos. Available at http://www.bbc.co.uk/news/world-south-asia-38909512

Sabran SF, Mohamed M \& Bakar MFA. 2016. Ethnomedical knowledge of plants used for the treatment of tuberculosis in Johor, Malaysia. Evidence Based Complement Alternative Medicine, 2016: 1-12.

Sam SABM \& Wee ST. 2014. Practice cultural of Orang Asli Jakun at Kampung Peta. International Journal of Conceptions on Management and Social Sciences, 2: 23572787

Stankey GH, Cole DN, Lucas RC, Petersen ME \& Frissell SS. 1985. The limits of acceptable change (LAC) system for wilderness planning. Ogden: USDA Forest Service. 
Tan AK. 2008. Protected area management in Indonesia and Malaysia: The challenge of divided competences between centre and periphery. In: Sodhi NS, Acciaioli G, Erb M \& Tan AK, eds. Biodiversity and human livelihoods in protected areas: Case studies from the Malay Archipelago. Cambridge: Cambridge University Press.

Traeholt C \& Sanusi M. 2009. Population estimates of Malay tapir, Tapirus indicus, by camera trapping in Krau Wildlife Reserve, Malaysia. Tapir Conservation, 18: 18-26

UNEP \& SCBD. 2001. Global Biodiversity. Available at http://www.cbd.int/gbo1/

Wassenhove LV. 2013. Singapore - A City in a garden: A vision for sustainability. Singapore: Insead.

Weaver DB. 1999. Magnitude of ecotourism in Costa Rica and Kenya. Annals of Tourism Research, 26: 792-816.

Whitmore TC. 1990. An introduction to tropical rainforests. Oxford: Oxford University Press.

Wong KM, Saw LG \& Kochummen KM. 1987. A survey of the forests of the EndauRompin area, Peninsular Malaysia: Principal forest types and floristic notes. Malayan Nature Journal, 41: 125-144.

Wood PL, Grismer LL \& Youmans TM. 2008. Amphibians and reptiles: Additions to the herpetofauna of Endau-Rompin, Johor, West Malaysia. Herpetological Review, 39: $112-121$.

Ying LC. 2014, $6^{\text {th }}$ October. Scientists and villagers search for ways to keep jumbos at bay. The Star Online. Available at http://www.thestar.com.my/news/environment/2014/10/06/searching-for-ways-to-keepjumbos-at-bay/

Yong DL. 2012. Massive deforestation in Southern Peninsular Malaysia driving ecological change in Singapore? Nature in Singapore, 5: 285-289 